DOI: 10.20472/EFC.2017.007.011

\author{
JACEK LIWINSKI \\ University of Warsaw, Poland
}

\title{
ARE SCHOOL-PROVIDED SKILLS USEFUL AT WORK? RESULTS OF THE WILES TEST
}

\begin{abstract}
:
Although it has been over 40 years since labour economists started testing human capital vs. signalling explanation of the wage premium from education, the debate is still going on and authors keep on proposing new methods of testing. The human capital theory postulates that investment in education enhances the productive capacity of individuals, while according to the signalling hypothesis the value of a graduation diploma follows from the fact that it signals innate abilities of its holder.

We apply the approach proposed by Wiles to test for the signalling hypothesis and, in particular, to find out if there is a positive relation between education and productivity. For this purpose, we construct a job match index based on information if school provided knowledge and skills are useful at work and the job performed is relevant to the field of study. Then we check if the quality of job matching is related to wages of graduates in Poland. To answer this question, a wage equation was estimated using OLS on the basis of data from a representative, nationwide tracer survey of Poles who left secondary schools or graduated from higher education institutions over the period of 1998-2005.

We find out that knowledge and skills acquired in the course of formal education bring wage benefits only to university graduates. Besides, this group receives a wage premium, which may be attributed to their high innate abilities. In sum, the outcomes are consistent with the weak signalling hypothesis, since they show that tertiary education signals a high level of innate abilities and at the same time it provides knowledge and skills which enhance individual productivity at work.

Besides, we find evidence of the strong signalling hypothesis with regard to the secondary vocational schools leavers.
\end{abstract}

\section{Keywords:}

education, human capital, signalling, job matching, wage equation

JEL Classification: J24, J31 


\section{Introduction}

For four decades, education economists have been disputing, whether formal education provides skills that are useful at work, or it is only a tool to signal high innate abilities to employers. The first approach follows the human capital theory (Becker 1964), according to which formal education provides knowledge and skills, thereby enhancing the productive capacity of individuals at work, which translates into higher wages under assumption of perfect competition in the labour market. The second, alternative explanation of the positive wage premium from education is proposed by Spence (1973), who argues that it may result from selection that takes place in the education process, where innate abilities are rewarded. In an extreme case, schooling may provide no skills useful at work whatsoever and be a signalling tool only (Arrow 1973; Stiglitz 1975). This case is termed the strong signalling hypothesis (SSH). Yet, it is also possible that education both signals abilities and provides some skills that are useful at work, then the wage premium reflects both these factors. A case like this is referred to as the weak signalling hypothesis (WSH) (Blaug, 1995; Groot and Hartog, 1995; Brown and Sessions, 2006).

The signalling hypothesis has been tested empirically in many different ways, with no conclusive results however (Brown and Sessions, 2004). One of the approaches, known as the Wiles test, verifies whether graduates receive any wage premium from performing a job which is relevant to their field of study (Wiles, 1974). A positive wage premium from a good job match may be interpreted as evidence of a positive impact of education on employee's productivity at work, which supports the human capital theory, and consequently leads to the rejection of the strong signalling hypothesis. If this coincides with a positive wage premium from education, the weak signalling hypothesis is supported. On the other hand, no wage premium from a good job match coexisting with a positive wage premium from education would validate the signalling theory.

The aim of this study is to test for the signalling hypothesis using the approach proposed by Wiles (1974) and, in particular, to find out if there is a positive relation between education and productivity. For this purpose we estimate an extended Mincer wage equation using OLS and data from a representative, nationwide tracer survey of Poles who left secondary schools or graduated from higher education institutions over the period of 1998-2005.

The paper is structured into three sections. The first chapter introduces previous studies where the Wiles test was used. The second section presents our own analysis of school knowledge and skills usefulness at work, performed using the Wiles test. We discuss successively: data, the analytical method, the results and stability tests. The paper ends with a summary of the most important conclusions. 


\section{Overview of empirical literature}

So far, the Wiles has been used in a few studies only, some of which prove a positive effect of education on the graduates' productivity (Arabsheibani, 1989; Zhu and Zhu, 2011), while others show that no such a relation occurs, the role of education being limited to its signalling function (Miller and Volker, 1984; FengLiang et al., 2009; van der Merwe, 2010). Thus, studies do not answer clearly, whether skills acquired in the course of formal education are useful at work. However, the results of analyses referred to above might have been affected by the fact that the Wiles test is applied slightly differently in each of them.

Firstly, the key variable of the model, which shows the relevance of the job to the field of study is not defined in the same way. According to Miller and Volker (1984), the relation exists, if the graduate has embarked on a profession where the skills acquired at school might potentially be useful. Arabsheibani (1989) and FengLiang, Xiaohao and Morgan (2009) use graduates' declaration that their current occupation is matched with the field of study as a job match measure. Zhu and Zhu (2011), on the other hand, use the job match index developed by Richards (1984), which is based on the respondents' declaration whether their current occupation was matched with their qualifications in terms of status and pay, usefulness of the skills acquired in their academic work, and the relationship between their job and the field of study.

Secondly, in some of the studies additional variables reflecting the stock of knowledge and skills acquired at school were included in the model, based on the assumption that the greater the stock, the higher the wage premium should be. Miller and Volker (1984) used information about graduating with honours and crossed it with a variable showing the relationship between the job and the field of study. FengLiang, Xiaohao and Morgan (2009) went even further, as they used two additional variables participation in extracurricular activities and grade point average, the latter being crossed with the variable reflecting the relationship between the job and the field of study.

Thirdly, the focus of all studies was solely on tertiary education graduates and some of them were even limited to some selected fields of study. The authors substantiate this choice with Rosen's suggestion (1972) that knowledge of the liberal arts should not directly produce the capacity to capture profit in the labour market, at least not during the period of undergraduate study. Hence, Miller and Volker (1984) focused on graduates with training in economics and those with training in science, Arabsheibani (1989) - on graduates of medical sciences, sciences and social sciences, while FengLiang, Xiaohao and Morgan (2009) - on graduates of engineering, sciences and social sciences. Zhu and Zhu (2011), on the other hand, divided fields of study according to the classification developed by Biglan (1973), into four groups: soft-pure (e.g. literature, history), soft-applied (e.g. economics, management), hard-pure (e.g. physics, chemistry) and hard-applied (e.g. computer science, electronics, mechanical engineering). 
Fourthly, the studies differed in terms of specification of the wage equation. Arabsheibani (1989), besides the variable reflecting the relationship between the job and the field of study, used only five control variables in the equation, while Zhu and Zhu (2011) estimated a model which contained as many as twenty control variables, including such factors as family origin, cognitive and non-cognitive skills, job search intensity and workplace characteristics.

It is the common feature of the studies that, following the suggestion made by Blaug (1976) and Riley (1979, S242), respondents' first earnings after graduation are the response variable in the model. This enables one to avoid considering how productivity is influenced by such factors as training or learning-by-doing, provided that the sample being analysed consists only of individuals without any professional experience at the time of graduation.

\section{Empirical analysis}

The aim of the study is to find out, based on the Wiles test, whether the knowledge and skills acquired over the years of schooling in Poland are thereafter used productively at work. Unlike previous studies, this one covers not only graduates of tertiary education, but secondary school leavers too. As a productivity measure, we used earnings received at the first job after leaving school or graduating from a higher education institution.

\section{Data}

The analysis is based on data from the nationwide tracer survey of Polish graduates conducted by the Central Statistical Office of Poland (GUS) in the years 2006-2007 (ASM 2008). The focus of the survey was on the professional activity of graduates of various school types over the period of the first three years after the completion of formal education, with special attention to the first job after graduation. The nationwide survey comprised a sample of 20251 persons who completed their formal education between 1 January 1998 and 31 December 2005 (at basic vocational schools, technical secondary schools, general secondary schools, post-secondary schools, higher education institutions). ${ }^{1}$ The study population was limited to individuals who did not exceed 27 years of age at the time when their schooling ended and the break between the next-to-last and the last stage of education was not longer that 12 months. ${ }^{2}$

The data base provides detailed information about the respondent's education process, the first job after the completion of the formal education and the relationship between this job and the field of study. Importantly to the context of this study, the respondents were asked to indicate (using a four-degree scale), how much their first job had been relevant to their field of study and to what extent the school provided

\footnotetext{
${ }^{1}$ A description of the system of education in Poland can be found in Eurydice (2006).

${ }^{2}$ A detailed description of the methodology can be found in ASM (2008).
} 
knowledge and skills had been useful at this work. Furthermore, the data base contains information about the grade point average from the last school completed, that can be considered as a measure of the amount of knowledge and skills acquired while studying there. Considering the potential endogeneity of the choice of education path, it is important that the database enable identification of each parent's education level, which can be indicative of the respondents innate abilities, to a certain degree.

The focus of empirical analysis is on the factors that influence secondary and tertiary school graduates' first wages earned at the first job after the completion of formal education, provided that the respondent undertook employment in the first year after graduation. Consequently, we eliminated the following respondent categories from the database: 1) individuals who did not work within the first year after ending formal education, 2) the self-employed and family members supporting them, since none of these groups was asked about earnings, 3) hired workers who did not disclose their first earnings. Eventually, the sample used for the analysis comprised 5783 observations.

Information about earnings is declarative, therefore the figures are not necessarily consistent with the actual situation, for such reasons as: reluctance to disclose the real earnings, the inability to recollect the actual amount earned, the tendency to round the figures. It is not possible to say, how these measurement errors affect the final result. Yet, the distribution of earnings is - as expected - unimodal and skewed to the right.

\section{Method of analysis}

Based on the overview of existing studies, the following wage equation was designed:

$$
\ln \left(w_{i}\right)=M_{i} \beta_{1}+S_{i} \beta_{2}+X_{i} \beta_{3}+\varepsilon_{i}
$$

where the dependent variable $\left(\boldsymbol{w}_{i}\right)$ is the school and university graduates' hourly rate of the first net earnings, provided that they undertook employment within the first year after graduation ${ }^{3}$, variable $\boldsymbol{M}_{i}$ reflects the quality of a job match, vector $\boldsymbol{S}_{i}$ contains variables that reflect the school-provided knowledge and skills, while vector $\boldsymbol{X}_{i}$ includes other factors that may influence earnings.

Using graduates' first earnings as a dependent variable is consistent with the suggestion made by Blaug (1976) and Riley (1979), as well as with the previous analytical practice. Besides, only those graduates who did not have any job at the time of graduation are included in the sample.

The key independent variable in the model, which reflects the quality of job match on the first job after graduation $\left(\boldsymbol{M}_{i}\right)$ is based on the Job Match Index. The Index was designed based on responses to two questions in the questionnaire:

\footnotetext{
${ }^{3}$ For the sake of comparability of the initial earnings of graduates who started their first job in different years (19982005), initial hourly rates were adjusted by the Consumer Price Index, with 2005 as the base year.
} 
Q1. Were the school/university provided knowledge and skills useful at your first job? Answers to be chosen from: (a) very useful, (b) rather useful, (c) not very useful, (d) not useful at all;

Q2. Was your first job relevant to your field of study? Answers to be chosen from: (a) definitely yes, (b) rather yes, (c) rather not, (d) definitely not.

The responses were scored from 0 to 3 points: answer (d) -0 points, answer (c) -1 point, answer (b) -2 points, answer (a) -3 points. Subsequently, both the scores were totalled, resulting in the Job Match Index (JMI). The Index takes seven values from 0 to 6 - where 0 represents an absolute uselessness of school-provided knowledge and no job-education match at all, while 6 means a very high level of knowledge usefulness at work which is entirely relevant to the field of study. Then, based on the Index a discrete variable $\left(\boldsymbol{M}_{i}\right)$ was created to identify three types of job matches with respect to their quality:

1. a good match - when the Index value is 5 or 6 ,

2. a poor match - when the Index value is 2 to 4 ,

3. no match - when the Index value is 0 or 1 .

This variable was included in the wage equation as a discrete variable, with "no match" being the base category.

The education level and the grade point average from the last school are the next two important variables $\left(\boldsymbol{S}_{i}\right)$ included in the model. They reflect the amount of knowledge and skills acquired at school, but at the same time they may signal high innate abilities. Thus, if variable $\boldsymbol{M}_{i}$ is a good measure of school-provided knowledge and skills that are useful at work, the education level and the grade point average would reflect innate abilities only. Hence, their significance in the wage equation would be indicating their signalling function.

There were five education levels distinguished and they represent the type of the last school completed and degree obtained in the process of formal education: 1 - basic vocational, 2 - secondary general, 3 - secondary vocational, 4 - tertiary, bachelor's or engineer's degree; 5 - tertiary, master's degree.

The grade point average in the Polish education system may fall between 2 and 6 , where 2 ("mediocre") is the lowest passing grade, while 6 ("excellent") is the highest grade that can be awarded. We divided the variable into three value classes: 1 - low grade (for the interval 2.0-3.5); 2 - average grade (for the interval 3.5-4.5); 3 - high grade (for the interval 4.5-6.0).

Furthermore, the model includes a wide range of control variables $\left(\boldsymbol{X}_{i}\right)$, that reflect:

- the process of education: field of study, ownership status of the last school or university completed, learning mode (full time, evening/part time), participation in extracurricular activities (foreign language classes, IT classes, sports and tourism, 
artistic activities, technical activities, scouting), professional practice when at school (paid job, voluntary work),

- the first job characteristics: profession, company ownership sector, company size, company economic sector,

- other individual characteristics of the respondent and of the local labour market: gender, age when first employed, each parent's education level, place of residence, region, year of leaving school.

A complete list of variables included in the wage equation is presented in Table A1. In order to eliminate outliers, we deleted $0.1 \%$ of observations with extreme values of the wage hourly rate, half from the lower and half from the upper end of the distribution. The linear regression model was estimated using OLS, by computing heteroscedasticity-resistant variance estimations. ${ }^{4}$

\section{Results}

In total, $41 \%$ of graduates from Polish schools and universities performed jobs that were well matched to their qualifications, $34 \%$ had a poorly matched job, while $25 \%$ had an unmatched job (Table 1). To sum it up, three fourths of graduates used at least some of the school-provided knowledge and skills at their first job. The percent of individuals performing a job which matched their qualifications was highest among vocational school leavers (61\%) and among graduates of master degree programs $(49 \%)$, as well as among graduates with a high grade point average from the last school (54\%). A good job matching was least common among general secondary school leavers $(9 \%)$, which is quite natural, as they have not acquired any vocational qualifications at school.

Table 1. Distributions of quality of job matching

\begin{tabular}{|l|c|c|c|}
\hline \multicolumn{1}{|c|}{ Model specification } & $\begin{array}{c}\text { Job match: } \\
\text { good }\end{array}$ & $\begin{array}{c}\text { Job match: } \\
\text { poor }\end{array}$ & $\begin{array}{c}\text { Job match: } \\
\text { none }\end{array}$ \\
\hline Total & 41.4 & 33.6 & 25.0 \\
\hline Females & 41.2 & 34.9 & 23.9 \\
\hline Males & 41.8 & 31.9 & 26.3 \\
\hline Education: basic vocational & 60.6 & 21.2 & 18.2 \\
\hline Education: secondary general & 8.6 & 46.3 & 45.1 \\
\hline Education: secondary vocational & 34.4 & 36.6 & 29.0 \\
\hline Education: tertiary & 49.2 & 33.5 & 17.2 \\
\hline Average grade: low & 40.3 & 31.3 & 28.4 \\
\hline Average grade: medium & 39.2 & 35.3 & 25.5 \\
\hline Average grade: high & 53.5 & 29.1 & 17.4 \\
\hline
\end{tabular}

\footnotetext{
${ }^{4}$ Initially, due to the suspected self-selection of the sample, the wage model was estimated using Heckman's twostep approach (Heckman 1979). Besides the variables present in the wage equation, three additional variables were used in the selection equation: marital status, number of children, family model (both / one of the parents working). Yet, since the results did not show any self-selection bias, we chose to estimate the linear regression model using OLS.
} 
Source: Author's own analyses based on unit data from the nationwide tracer survey of Polish graduates conducted in 2007.

Table 2 shows the average hourly earnings rate paid to graduates at their first job, computed for individual value classes of the basic variables in the model. These data show that individuals with a good job match earn ca. $12 \%$ more than those whose qualifications are entirely irrelevant to their job. Yet, this difference may be due to differences between these two groups with respect to other individual characteristics which are conducive to performing a well matched job and to obtaining high earnings at the same time. To find out if this is really the case, a regression analysis is required.

Table 2. Descriptive statistics of the dependent variable

\begin{tabular}{|l|c|c|c|}
\hline \multicolumn{1}{|c|}{ Model specification } & $\begin{array}{c}\text { Mean of } \\
\text { hourly earnings } \\
\text { (PLN) }\end{array}$ & $\begin{array}{c}\text { Standard } \\
\text { deviation }\end{array}$ & $\mathrm{N}$ \\
\hline Total & 6.31 & 4.96 & 5783 \\
\hline Job match: good & 6.71 & 4.94 & 2396 \\
\hline Job match: poor & 6.06 & 4.74 & 1943 \\
\hline Job match: none & 5.97 & 5.25 & 1444 \\
\hline Females & 6.05 & 4.50 & 3265 \\
\hline Males & 6.65 & 5.48 & 2518 \\
\hline Education: basic vocational & 5.56 & 4.47 & 1214 \\
\hline Education: secondary general & 5.78 & 4.30 & 743 \\
\hline Education: secondary vocational & 5.73 & 4.76 & 1936 \\
\hline Education: tertiary & 7.59 & 5.44 & 1890 \\
\hline Average grade: low & 5.91 & 4.92 & 1224 \\
\hline Average grade: medium & 6.27 & 5.06 & 3759 \\
\hline Average grade: high & 7.09 & 4.46 & 800 \\
\hline
\end{tabular}

Source: Author's own analyses based on unit data from the nationwide tracer survey of Polish graduates conducted in 2007.

The results of the wage equation estimations are presented in Table 3. Specification (1) includes only one explanatory variable - the one reflecting the quality of job matching $\left(\boldsymbol{M}_{i}\right)$. Both the good and the poor job match are positively correlated with earnings. However, as four groups of control variables are added to the model one by one (specifications 2-6), this correlation gradually decreases, which means that the factors that determine earnings are, in general, positively correlated with the quality of job matching. The results of estimating the specification (6) - the one with the complete set of control variables - prove that only a good job match (as compared with no matching) is positively correlated with graduates' earnings but this relationship is observed for a $10 \%$ significance level only. Graduates, whose job is well matched to their qualifications, earn by $3.5 \%$ more. A poor job match does not show any statistically significant relationship with earnings. Furthermore, graduates gain a $20 \%$ wage premium from tertiary education (as compared with the basic vocational schooling). There is no correlation between the grade point average and earnings. 
The findings reported above seem to support the weak signalling hypothesis. This conclusion follows from the coexistence of two findings: the positive, although weak, correlation of job matching with earnings, which is consistent with human capital view that school-provided skills enhance productivity, and the positive wage premium from tertiary education, which, according to the signalling theory, can be attributed to tertiary graduates' greater innate abilities.

Table 3. Estimations of the graduate's first wage equation

\begin{tabular}{|c|c|c|c|c|c|c|}
\hline Model specification & (1) & (2) & (3) & (4) & (5) & (6) \\
\hline Job match: good & $0.143^{\star \star \star}$ & $0.119^{\star \star *}$ & $0.115^{\star \star \star}$ & $0.085^{\star \star \star}$ & $0.083^{\star * *}$ & $0.035^{*}$ \\
\hline Job match: poor & $0.046^{\star *}$ & 0.022 & 0.022 & 0.002 & 0.002 & -0.017 \\
\hline Education: secondary general & & $0.096^{* * *}$ & $0.094^{* * *}$ & $0.091^{* * *}$ & 0.054 & 0.058 \\
\hline Education: secondary vocational & & $0.054^{\star \star \star}$ & $0.051^{\star \star \star}$ & $0.063^{\star \star \star}$ & $0.044^{*}$ & 0.035 \\
\hline Education: tertiary & & $0.306^{\star \star \star}$ & $0.296^{\star \star \star}$ & $0.320^{\star \star \star}$ & $0.274^{\star \star \star}$ & $0.208^{\star * *}$ \\
\hline Average grade: high & & & -0.009 & 0.016 & 0.005 & 0.011 \\
\hline Average grade: medium & & & $0.050^{\star *}$ & $0.071^{* \star *}$ & $0.041^{*}$ & 0.041 \\
\hline $\begin{array}{l}\text { Demographic, family background } \\
\text { and local labour market }\end{array}$ & & & & + & + & + \\
\hline Other educational characteristics & & & & & + & + \\
\hline Job characteristics & & & & & & + \\
\hline Number of observations & 5,810 & 5,810 & 5,810 & 5,810 & 5,810 & 5,783 \\
\hline $\mathrm{R} 2$ & 0.013 & 0.068 & 0.070 & 0.148 & 0.166 & 0.191 \\
\hline
\end{tabular}

Notes: All independent variables are listed in Table $1 \mathrm{~A}$, in the Appendix.; ${ }^{* \star * / * * / *}$ stand for $1 \%, 5 \%$ and $10 \%$ significance respectively.

Source: Author's own analyses based on unit data from the nationwide tracer survey of Polish graduates conducted in 2007.

\section{Heterogeneity}

Table 4 shows that a wage premium from the job match goes to graduates who demonstrate some specific characteristics. Firstly, it is received by women, but not by men. Secondly, a very high wage premium, both from a good and a poor job match, goes to university graduates, while those who left school having completed the secondary education level earn no such premium at all. Thirdly, the job match is positively correlated with the earnings of graduates with a good grade point average, contrary to those who performed at school acceptably, or very well.

Both women and individuals which good school grades, earn not only a premium from the good job match, but also a wage premium from tertiary education, which may be evidence of two factors concurrently influencing their earnings: the human capital accumulation, and the signalling of innate abilities. As far as men are concerned, the situation is consistent with the strong signalling hypothesis, since they receive a premium from tertiary and secondary vocational education, as well as from very good grades, but not from a good or a poor job match. 
Tertiary education seems to play a key role in providing knowledge and skills that are useful at work. While women and persons achieving good grades at school receive a relatively low wage premium (4\%) from a good job match, which is significant at $10 \%$ level only, the premium ensured by tertiary education is four time as high (16\%), at $1 \%$ significance level.

What is more, as deeper analysis, presented in Table 5, proves, both female and male university graduates earn a wage premium from a good job match $-14 \%$ and $17 \%$ respectively - while women or men who finished their formal education after leaving any of the three secondary school types earn no such premium at all.

Table 4. Estimations of the graduate's first wage equation by gender, education level and average grade

\begin{tabular}{|c|c|c|c|c|c|c|c|c|c|c|}
\hline \multirow{2}{*}{ Model specification } & \multirow[b]{2}{*}{ Total } & \multicolumn{2}{|c|}{ Gender } & \multicolumn{4}{|c|}{ Educational level } & \multicolumn{3}{|c|}{ Average grade } \\
\hline & & female & male & $\begin{array}{c}\text { basic } \\
\text { vocational }\end{array}$ & \begin{tabular}{|c|} 
secondary \\
general
\end{tabular} & $\begin{array}{l}\text { secondary } \\
\text { vocational }\end{array}$ & tertiary & low & medium & high \\
\hline Job match: good & $0.035^{\star}$ & $0.043^{*}$ & 0.017 & -0.056 & 0.097 & -0.035 & $0.165^{\star * \star}$ & -0.023 & $0.041^{*}$ & 0.062 \\
\hline Job match: poor & -0.017 & 0.011 & -0.041 & $-0.110^{* *}$ & -0.045 & -0.030 & $0.090^{* *}$ & $-0.132^{* * *}$ & 0.011 & 0.013 \\
\hline Education: secondary general & 0.058 & 0.020 & 0.094 & & & & & -0.008 & 0.054 & 0.067 \\
\hline Education: secondary & 0.035 & -0.003 & $0.060^{*}$ & & & & & 0.040 & 0.026 & 0.034 \\
\hline Education: tertiary & $0.208^{* * *}$ & $0.150^{* * *}$ & $0.247^{* * *}$ & & & & & 0.108 & $0.200^{* * *}$ & 0.184 \\
\hline Average grade: high & 0.011 & -0.004 & 0.021 & 0.014 & -0.014 & 0.001 & 0.033 & & & \\
\hline Average grade: medium & 0.041 & 0.002 & $0.091^{* *}$ & 0.092 & 0.035 & 0.015 & 0.042 & & & \\
\hline Number of observations & 5,783 & 3,265 & 2,518 & 1,214 & 743 & 1,936 & 1,890 & 1,224 & 3,759 & 800 \\
\hline R2 & 0.191 & 0.230 & 0.176 & 0.159 & 0.218 & 0.172 & 0.199 & 0.191 & 0.194 & 0.332 \\
\hline
\end{tabular}

Table 5. Estimations of the graduate's first wage equation by gender and education level

\begin{tabular}{|l|c|c|c|c|c|c|c|c|}
\hline \multirow{2}{*}{ Model specification } & \multicolumn{4}{c|}{ Females } & \multicolumn{4}{c|}{ Males } \\
\cline { 2 - 10 } & $\begin{array}{c}\text { basic } \\
\text { vocational }\end{array}$ & $\begin{array}{c}\text { secondary } \\
\text { general }\end{array}$ & $\begin{array}{c}\text { secondary } \\
\text { vocational }\end{array}$ & tertiary & $\begin{array}{c}\text { basic } \\
\text { vocational }\end{array}$ & $\begin{array}{c}\text { secondary } \\
\text { general }\end{array}$ & $\begin{array}{c}\text { secondary } \\
\text { vocational }\end{array}$ & tertiary \\
\hline Job match: good & 0.001 & 0.051 & -0.038 & $0.142^{* * *}$ & -0.035 & 0.153 & -0.029 & $0.169^{* * *}$ \\
\hline Job match: poor & -0.014 & -0.022 & -0.019 & $0.086^{*}$ & -0.076 & -0.145 & -0.024 & 0.112 \\
\hline Average grade: high & 0.021 & -0.049 & 0.055 & $-0.145^{* *}$ & 0.022 & 0.012 & -0.037 & $0.209^{* *}$ \\
\hline Average grade: medium & 0.080 & -0.038 & 0.029 & $-0.144^{*}$ & $0.161^{*}$ & -0.049 & 0.067 & $0.209^{* *}$ \\
\hline Number of observations & 504 & 471 & 1,062 & 1,228 & 710 & 272 & 874 & 662 \\
\hline R2 & 0.262 & 0.280 & 0.187 & 0.235 & 0.199 & 0.307 & 0.223 & 0.262 \\
\hline
\end{tabular}

\section{Conclusions}

The aim of the study has been to test for the signalling hypothesis using the approach proposed by Wiles (1974) and, in particular, to find out whether the knowledge and skills acquired over the years of schooling in Poland are thereafter used productively at work. Unlike previous studies, this one covers not only tertiary education graduates, but secondary school leavers too.

The findings are as follows:

1. The weak signalling hypothesis can be supported for university graduates, both women and men.

2. The strong signalling hypothesis can be supported for men who finished their formal education after leaving secondary technical schools (as compared with 
basic vocational school leavers). Their first earnings are by $6 \%$ more than those of basic vocational school leavers, and this difference can be attributed to the greater innate abilities of the former.

\section{Appendix}

Table A1. Independent variables included in the wage equation

\begin{tabular}{|c|c|}
\hline Independent variable & Value classes \\
\hline Job match & $\begin{array}{l}1-\text { good (the Job Match Index equals } 5 \text { or } 6 \text { ); } \\
2-\text { poor (the Job Match Index ranges from } 2 \\
\text { to } 4 \text { ); } \\
3^{*}-\text { none (the Job Match Index equals } 0 \text { or } \\
\text { 1). }\end{array}$ \\
\hline Job match 1 (alternative definition) & $\begin{array}{l}1-\text { good (the Job Match Index equals } 6 \text { ); } \\
2-\text { poor (the Job Match Index ranges from } 1 \\
\text { to } 5 \text { ); } \\
3^{*}-\text { none (the Job Match Index equals } 0 \text { ). }\end{array}$ \\
\hline Job match 2 (alternative definition) & $\begin{array}{l}1-\text { good (the Job Match Index ranges from } 4 \\
\text { to } 6 \text { ); } 2 \text { - poor (the Job Match Index equals } \\
3 \text { ); } \\
3^{*}-\text { none (the Job Match Index ranges from } \\
0 \text { to } 2 \text { ) }\end{array}$ \\
\hline Education & $\begin{array}{l}1^{*} \text { - basic vocational; } 2 \text { - general secondary; } \\
3 \text { - secondary vocational (secondary } \\
\text { technical, profiled secondary, post- } \\
\text { secondary); } 4 \text { - tertiary, bachelor's or } \\
\text { engineer's degree; } 5 \text { - tertiary, master's } \\
\text { degree }\end{array}$ \\
\hline $\begin{array}{l}\text { Grade point average (on the diploma } \\
\text { or certificate of the last school or } \\
\text { university attended) }\end{array}$ & $\begin{array}{l}1^{*} \text { - low grade (ranging 2.0-3.5); } 2 \text { - average } \\
\text { grade (ranging 3.5-4.5); } 3 \text { - high grade } \\
\text { (ranging 4.5-6.0). }\end{array}$ \\
\hline Field of study & $\begin{array}{l}1 \text { - teacher education, pedagogy; } 2 \text { - foreign } \\
\text { languages; } 3 \text { - humanities; } 4 \text {-art; } 5 \text { - } \\
\text { business administration and marketing; } 6 \text { - } \\
\text { social sciences; } 7 \text { - economics; } 8 \text { - law; } 9 \text { - } \\
\text { administration; } 10 \text { - natural sciences; } 11 \text { - } \\
\text { physical sciences; } 12 \text { - mathematics, } \\
\text { statistics; } 13 \text { - information technology; } 14 \text { - } \\
\text { engineering and technology; } 15 \text { - production } \\
\text { and processing; } 16 \text { - architecture and } \\
\text { construction; } 17 \text { - agriculture, forestry, } \\
\text { fishery; } 18 \text { - services; } 19 \text { - healthcare, social } \\
\text { services; } 20 \text { - military/police; } 21-\text { security } \\
\text { and safety; } 22 \text { - general programs; } 23^{*}- \\
\text { other. }\end{array}$ \\
\hline $\begin{array}{l}\text { Ownership status of the last school or } \\
\text { university attended }\end{array}$ & $1^{*}$ - public; 2 - non-public. \\
\hline Schooling mode & $1^{*}$ - full time; 2 - evening / part time. \\
\hline
\end{tabular}




\begin{tabular}{|c|c|}
\hline $\begin{array}{l}\text { Employment in the schooling period: } \\
\text { paid jobs }\end{array}$ & $1-$ yes; $2^{*}-$ no. \\
\hline $\begin{array}{l}\text { Employment in the schooling period: } \\
\text { voluntary activities }\end{array}$ & $1-$ yes; $2^{*}-$ no. \\
\hline Occupation & $\begin{array}{l}\text { Binary variables for major groups of } \\
\text { occupations according to ISCO- } 08 \text {. }\end{array}$ \\
\hline Company ownership sector & $1^{*}$ - public; 2 - private; 3 - public-private. \\
\hline Company size & $\begin{array}{l}1^{*}-\text { up to } 9 \text { employees; } 2-10-49 \\
\text { employees; } 3-50-249 \text { employees; } 4-250 \\
\text { employees or more. }\end{array}$ \\
\hline Company economic sector & 1 - agriculture; 2 - industry; $3^{*}$ - services. \\
\hline Gender & $1^{*}-$ woman; $2-\operatorname{man}$ \\
\hline Age when first employed & continuous variable \\
\hline Father's education & $\begin{array}{l}1^{*} \text { - primary or less; } 2 \text { - basic vocational; } 3 \\
\text { - secondary (general, vocational, post- } \\
\text { secondary); } 4 \text { - tertiary; } 5 \text { - unknown }\end{array}$ \\
\hline Mother's education & $\begin{array}{l}1^{*} \text { - primary or less; } 2 \text { - basic vocational; } 3 \\
\text { - secondary (general, vocational, post- } \\
\text { secondary); } 4 \text { - tertiary; } 5 \text { - unknown }\end{array}$ \\
\hline $\begin{array}{l}\text { Extracurricular activities: language } \\
\text { classes }\end{array}$ & $\begin{array}{l}1 \text { - participation in extracurricular organised } \\
\text { foreign language classes at the last stage } \\
\text { of schooling; } 2^{*}-\text { no participation }\end{array}$ \\
\hline Extracurricular activities: IT classes & $\begin{array}{l}\text { 1- participation in extracurricular organised } \\
\text { IT classes at the last stage of schooling; } \\
2^{*}-\text { no participation }\end{array}$ \\
\hline $\begin{array}{l}\text { Extracurricular activities: sports and } \\
\text { tourism }\end{array}$ & $\begin{array}{l}1 \text { - participation in extracurricular organised } \\
\text { sports or tourist activities at the last stage } \\
\text { of schooling; } 2^{*}-\text { no participation }\end{array}$ \\
\hline $\begin{array}{l}\text { Extracurricular activities: artistic } \\
\text { activities }\end{array}$ & $\begin{array}{l}1 \text { - participation in extracurricular organised } \\
\text { artistic activities at the last stage of } \\
\text { schooling; } 2^{*}-\text { no participation }\end{array}$ \\
\hline $\begin{array}{l}\text { Extracurricular activities: technical } \\
\text { activities }\end{array}$ & $\begin{array}{l}1 \text { - participation in extracurricular organised } \\
\text { technical classes at the last stage of } \\
\text { schooling; } 2^{*}-\text { no participation }\end{array}$ \\
\hline Extracurricular activities: scouting & $\begin{array}{l}1 \text { - participation in scout meetings at the last } \\
\text { stage of schooling; } 2^{*}-\text { no participation }\end{array}$ \\
\hline Place of residence & $\begin{array}{l}1^{*}-\text { rural; } 2-\text { town } \leq 100,000 \text { inhabitants; } 3 \\
- \text { town }>100,000 \text { inhabitants }\end{array}$ \\
\hline Region (voivodship) & $\begin{array}{l}1^{*} \text { - Dolnośląskie; } 2 \text { - Kujawsko-Pomorskie; } \\
3 \text { - Lubelskie; } 4 \text { - Lubuskie; } 5 \text {-Łódzkie; } 6 \\
\text { - Małopolskie; } 7 \text { - Mazowieckie; } 8 \text { - } \\
\text { Opolskie; } 9 \text {-Podkarpackie; } 10 \text { - Podlaskie; } \\
11 \text { - Pomorskie; } 12 \text { - Śląskie; } 13 \text { - } \\
\text { Świętokrzyskie; } 14 \text { - Warmińsko-Mazurskie; } \\
\text { 15-Wielkopolskie; } 16 \text { - } \\
\text { Zachodniopomorskie }\end{array}$ \\
\hline Year of leaving school & Binary variables for the years $1998-2005$ \\
\hline
\end{tabular}




\section{References}

ARROW K.J. (1973), Higher Education as a Filter, Journal of Public Economics, 2 (3), pp. 193-216.

ARABSHEIBANI G. (1989), The Wiles test revisited, Economics Letters, 29, pp. 361-364.

ASM (2008), Badanie aktywności zawodowej absolwentów w kontekście realizacji programu „Pierwsza praca”. Analiza wyników badania, Ministerstwo Pracy i Polityki Społecznej. Departament Rynku Pracy, Warszawa.

BECKER G.S. (1964), Human capital: A theoretical and empirical analysis, with special reference to education, National Bureau of Economic Research, New York.

BIGLAN A. (1973), The characteristics of subject matter in different academic areas, Journal of Applied Psychology, 57 (3), pp. 195-203.

BLAUG M. (1976), The empirical status of human capital theory: a slightly jaundiced survey, Journal of Economic Literature, 14 (3), pp. 827-855.

BLAUG M. (1995), The wage contract and education. In: Carnoy M. (Ed.), International Encyclopedia of Economics of Education (Second Edition). Pergamon Press and Elsevier Science, Oxford, pp. 44-52.

Brown S., Sessions J.G. (2004), Signalling and Screening. In: G. Johnes and J. Johnes, eds., International Handbook on the Economics of Education. Cheltenham: Edward Elgar.

BROWN S., SESSIONS J.G. (2006), Evidence on the relationship between firm-based screening and the returns to education, Economics of Education Review 25 (5), pp. 498-509.

EURYDICE (2006) The System of Education in Poland, Foundation for the Developmant of the Education System, Warsaw.

FENGLIANG L., XIAOHAO D., MORGAN W.J. (2009), Higher Education and the starting wages of graduates in China, International Journal of Educational Development, 29, pp. 374-381.

GROOT W., HARTOG J. (1995), Screening models and education. In: Carnoy, M. (Ed.), International Encyclopedia of Economics of Education (Second Edition). Pergamon Press and Elsevier Science, Oxford, pp. 34-38.

HECKMAN J. (1979), Sample Selection Bias as a Specification Error, Econometrica, No 1.

MILLER P. W., VOLKER P. A. (1984), The screening hypothesis: an application of the Wiles test, Economic Inquiry, 22, pp. 121-127.

RICHARDS E. (1984), Early employment situations and work role satisfaction among recent college graduates, Journal of Vocational Behavior, 24, pp. 305-318.

RILEY J.G. (1979) Testing the educational screening hypothesis, Journal of Political Economy, 87 (5), pp. S227-S251.

ROSEN S. (1972) Learning and experience in the labour market, Journal of Human Resources, 12 (3), pp. 326-342.

SPENCE A.M. (1973), Job Market Signaling, Quarterly Journal of Economics, 87 (3), pp. 355-374.

STIGLITZ J.E. (1975), The Theory of „Screening”, Education and the Distribution of Income, The American Economic Review, Vol. 65, No. 3, pp. 283-300.

WILES P. (1974), The correlation between education and earnings: the External-Test-Not-Content hypothesis, Higher Education, 3 (1), pp. 43-58. 